\title{
INFLATION EXPECTATIONS IN THE CZECH INTERBANK MARKET
}

\author{
Martin Fukač
}
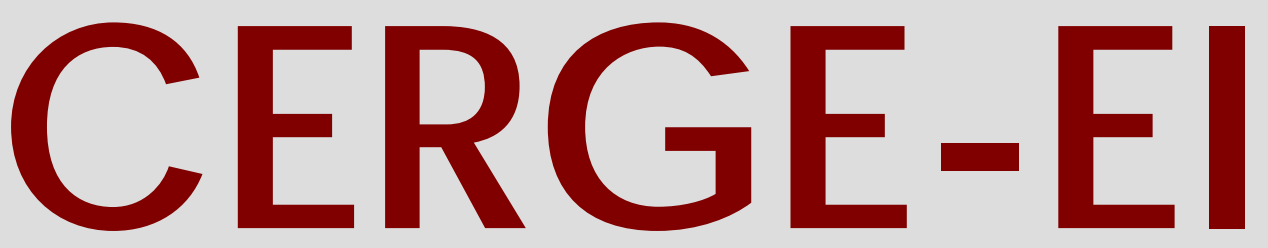

Charles University Centerfor Economic Research and Graduate Education Academy of Sciences of the Czech Republic Ec onomic s Institute 


\section{Working Paper Series \\ 253 \\ (ISSN 1211-3298)}

\section{Inflation Expectations in the Czech Interbank Market}

Martin Fukač

CERGE-EI

Prague, March 2005 
ISBN 80-7343-046-0 (Univerzita Karlova v Praze, CERGE)

ISBN 80-7344-035-0 (Národohospodářský ústav AV ČR, Praha) 


\title{
Inflation Expectations in the Czech Interbank Market
}

\author{
Martin Fukač ${ }^{*}$
}

Last version: 19/12/2004

\begin{abstract}
Monthly data on the inflation expectations of financial analysts in the Czech Republic exhibit a tendency for permanent bias and ineffectiveness which violates the rational expectations hypothesis assumed in macroeconomic models. This paper asks whether the surveyed data include any monetary-policy relevant information, in other words, whether the surveyed expectations correspond to the true market expectations, and hence should be reflected in macro models of the Czech economy instead of the rational expectations hypothesis. Using a methodology based on a simple Fisher rule, it is found that the difference between the surveyed and market expectations is not statistically significant.
\end{abstract}

\begin{abstract}
Abstrakt
Inflační očekávání na českém finančním trhu měřená Českou Národní Bankou vykazují při srovnání se skutečnou inflací tendence být vychýlená a nevydatná, což porušuje předpoklady hypotézy racionálních očekávání standardně přijímané při makroekonomickém modelování. Tento článek zkoumá otázku, zda tato očekávání představují relevantní informaci pro monetární politiku, jinými slovy zda měřená očekávání jsou shodná se skutečným tržním očekáváním a tudíž jejich charakter by měl být zohledněn $v$ makroekonomických modelech české ekonomiky místo předpokladu o jejich racionalitě. Metodologie založená na Fisherově vztahu mezi nominální úrokovou mírou a očekávanou inflací naznačuje, že rozdíl mezi měřenými a skutečnými očekáváními není statisticky významný.
\end{abstract}

Keywords: inflation expectations, nominal interest rate, Fisher rule JEL classification: C52, E43, E44

\footnotetext{
* Center for Economic Research and Graduate Education of Charles University in PragueEconomics Institute of the Academy of Sciences of the Czech Republic, (CERGE-EI), Politických vězňů 7, 11121 Prague 1, Czech Republic; e-mail: martin.fukac@cerge-ei.cz The author would like to thank Jordi Galí, Michal Kejak, Evžen Kočenda, Jan Kmenta, and Peter Tóth for helpful discussions and comments. The author is also grateful to Laura Mentz for her excellent editing assistance. The support from the World Bank Research Fellowship and the grant support from

GAČR No.402/02/0393 is also appreciated. The usual disclaimer applies.
} 


\section{Introduction}

The Czech National Bank runs monthly surveys on the inflation expectations of major institutions operating on the Czech financial market. In this paper we analyze the role of these expectations in the formation of prices in the Czech Interbank money market. The question we ask is: To what extent do the surveyed expectations correspond to the true market expectations? Put differently, do the surveyed expectations include any monetary-policy relevant information?

Figures 1 and 2 provide a motivation for asking these questions. A simple plot of the surveyed expectations and the actual inflation rate in Figure 1 reveals that the expectations can hardly be accepted given what economic theory assumes by the rational expectations hypothesis $(\mathrm{REH}){ }^{1}$ We observe a tendency for the permanent overshooting of expectations, and the two series do not follow a common trend, either. In general, there might be doubt about the seriousness of the forecasts. What is remarkable, though, is that in Figure 2 we observe very similar behavior of the money-market price (PRIBOR - Prague Interbank Offer Rate) and of the surveyed expectations.

Economists and policy-makers should be interested in whether the surveyed data have any information content, i.e., whether the financial analysts' expectations have any impact on the market activity. On the Czech data we

\footnotetext{
${ }^{1}$ When speaking about rationality, it is meant that the REH is satisfied. When using a term such as "irrationality", we mean the inefficiency of expectations (in the sense of the REH), understanding that that the violation of the REH does not necessarily bring about irrational behavior. The formal test for the REH is reported in Appendix C.
} 
may observe an interesting paradox. In Figure 1, we can see that the expectations do not have any predictive power for the actual inflation rate. However, given Figure 2, it seems the expectations influence the money market activity.

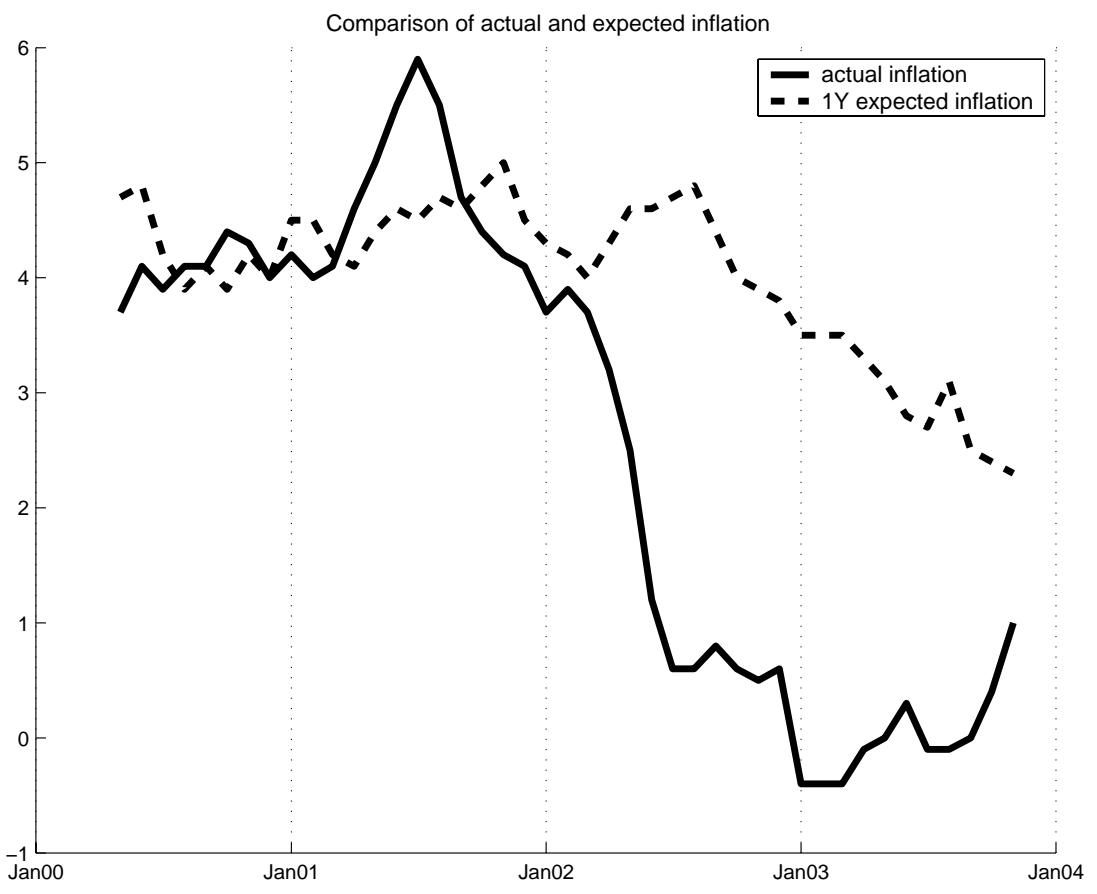

Figure 1 Comparison of inflation expectations and actual inflation 


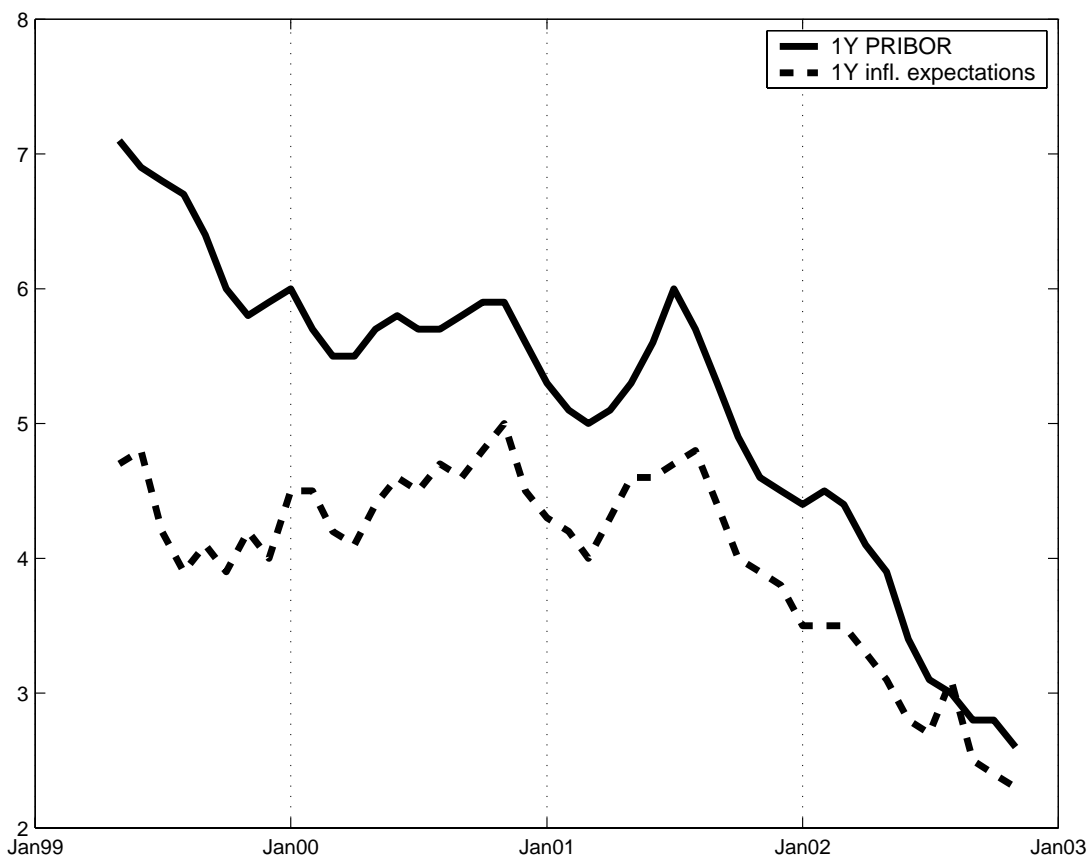

Figure 2 Comparison of inflation expectations and PRIBOR 1Y

Forming expectations is an essential part of any optimal decision making of any individual. Macroeconomic theory builds on the rational expectation hypothesis. As can be found in any standars textbook, agents or groups of agents use all the available information, including the costs of the process, as well as they can in their decisions. Certainly, because agents are heterogenous (they face different information utilization costs, they have different information sets available, etc.), expectations about the future differ. For the REH it is important, however, that the expectations are on average (of all individuals) unbiased and efficient, i.e., on the aggregate level the expectations correspond to reality with minor and random differences only. 
Recently Mankiw and Wolfers (2003) provided empirical evidence (for the American economy) that inflation expectations differ for different groups of agents (households, firms, academics, professional forecasters, etc.), which they explain by a sticky information model. According to their model, the disagreement in expectations varies with the state of the economy. However, over all economy states financial analysts form the most efficient and consistent inflation forecasts from all the groups Mankiw and Wolfers study. If we assume that this applies to the Czech economy as well, it calls into question why the forecasts in Figure 1 are inefficient and inconsistent and why they still have predictive power on the price on the Interbank market which ought to be competitive.

In this paper we only deal with the expectations of a single group of people, financial analysts. As such, one would think that what we observe in Figure 1 is irrelevant for judging the applicability of the assumptions of the REH which require we survey a representative sample over all economic agents (households, firms, financial intermediators, etc.). However, this paper is based on the fact that the interbank money market is dominant in the Czech financial system, unlike the US market. The CNB surveys a representative sample of financial analysts who represent the major market-makers on the Czech interbank market. The price the marker-makers create (PRIBOR) strongly influence other financial market prices (credit, swap market prices, etc.). Thus, if the financial analysts' expectations play a role in the determination of PRIBOR, then judging their properties from the REH perspective may be acceptable. 
Given the question of interest, the null hypothesis is formulated as that the surveyed expectations are equal to the true market ones. As a common part of any standard macroeconomic model, the Fisher rule is the cornerstone of the methodology employed here. Fama and Gibbons (1982), Mishkin (1990a) and Mishkin (1990b) provide a motivation for this approach. ${ }^{2}$

A careful reader will have already noticed that this paper views the money market from the macroeconomic perspective, and that it will be abstracted from the real mechanism of how the market functions, i.e., how the market price is actually formed.

Certainly, the market-makers also take into account other information than inflation forecasts (expectations). One does not know, however, whether the expectations are unintentionally transmitted in to the price via the information that the market-makers utilize or not. In the section of this paper devoted to the interpretation of results, a possible explanation for such a transmission is offered.

The rest of the paper is structured as follows. The methodology is formulated in the next section. Estimation results and their interpretation follow in section 3, and the fourth section concludes with a discussion of results.

\footnotetext{
${ }^{2}$ Another possibility how to view the Fisher rule, except of the standard view it is a product of economic agents optimal behavior, it can also be viewed as a simple monetary-policy rule.
} 


\section{The Methodology}

The methodology developed in this section is structured so that the stated question of interest "To what extent do the surveyed expectations correspond to the true market expectations?" is addressed. To this purpose the null hypothesis is formulated as "The market expectations coincide with the surveyed expectations".

Testing $\mathrm{H}_{0}$, similar to Fama and Gibbons (1982), Mishkin (1990a) and Mishkin (1990b), the Fisher rule is assumed as the true pricing rule for the money market, i.e.,

$$
i_{t}^{m}=\prod_{t, m}{ }^{e}-r_{t}^{m},
$$

where $\mathrm{i}_{\mathrm{t}}^{\mathrm{m}}$ is the nominal interest rate valid from the beginning of period $\mathrm{t}$ to $\mathrm{t}+\mathrm{m}$, $\Pi_{\mathrm{t}, \mathrm{m}}{ }^{\mathrm{e}}$ are the true market expectations formed at the beginning of period $\mathrm{t}$ for the $t+m$ time horizon, and $r_{t}^{m}$ is the corresponding ex ante real interest rate. As discussed in the introduction, the Fisher rule is assumed in its basic form without a risk premium which is implicitly assumed to be equal to zero.

In a standard way, let us assume that the inflation expectations are based on information $\Omega$ available at time t. Furthermore, following assumptions common to the literature, let us assume that the market inflation expectations at time $t$ for the $t+m$ horizon are equal to the actual inflation rate $\pi_{t+m}$, but are subject to disturbances $\varepsilon_{t+m}$. Formally written, 


$$
\Pi_{t, m}{ }^{e}=E\left(\pi_{t+m} \mid \Omega_{t}\right)=\pi_{t+m}+\varepsilon_{t+m} .
$$

Under the REH it holds that $\varepsilon_{t+m}$ is i.i.d. with zero mean and finite variance. If the mean is non-zero, then the expectations are biased. If the expectation error follows a stationary process with zero mean, the expectations are so-called weakly rational. The non-zero autocovariance structure causes only inefficiency of expectations but does not affect their consistency. For test convenience, no particular form of the market expectations will be prescribed, hence they can be both rational or weakly rational.

For our purposes, it is not important to know the exact process unanticipated inflation follows. The objective is to find the relation of the surveyed expectations to the market ones, i.e., whether these two are the same or if there is a difference. Thus, to test the null hypothesis, it is convenient and sufficient to keep the error in expectations in a nearly unspecified form.

Substituting (2) in (1) yields

$$
i_{t}^{m}=\pi_{t+m}+\varepsilon_{t+m}-r_{t}^{m},
$$

which can be further rewritten in a more suitable form for the empirical test as

$$
\mathrm{i}_{\mathrm{t}}=\phi_{0}+\phi_{1} \pi_{\mathrm{t}+12}+\mathrm{v}_{\mathrm{t}},
$$


where (putting $m=12$; we are going to deal with monthly data), $\phi_{0}=E\left(\phi_{1} \varepsilon_{t}-r_{t}\right)$, and $v_{t}=\phi_{1} \varepsilon_{t}-r_{t}-\phi_{0}=\phi_{1}\left(\Pi_{t, 12}^{e}-\pi_{t+12}\right)-r_{t}-\phi_{0}$. As indicated, $E\left(\varepsilon_{t}\right)$ can be different from zero. ${ }^{3}$ Because it is unsure that the market expectation error has a zero mean, no a priori unbiasedness condition on the expectations is imposed. Without loss of generality, the parameter $\phi_{1}$ is included. As Mishkin (1990b) shows, the parameter $\phi_{1}$ does not necessarily need to be equal to 1 . Its value depends on the correlation between the inflation expectations and the real interest rate. In this light, $\phi_{1}=1$ counts only for a special case.

Note that for $v_{t}$ in formulation (4), one is not able to separate the real interest rate from the expectation error. It is impossible to distinguish what part of the variation of $v_{t}$ accounts for the unanticipated inflation and what part accounts for the real ex ante interest rate. In other words, one is not even able to extract the error in the market inflation expectations from $v_{t}$, and to learn the expectations' exact form. That is why the null hypothesis is formulated as below, i.e., there is a correspondence between the surveyed expectations (which are observed) and the market expectations (which are unobservable).

The error term in expression (4), due to its generality, can be written for the market expectations and survey expectations separately:

$$
v_{t}=\phi_{1}\left(\Pi_{t, 12}^{e}-\pi_{t+12}\right)-r_{t}-\phi_{0}
$$

and

\footnotetext{
${ }^{3}$ In the opposite case, the parameter $\phi_{0}$ only catches the average ex ante real interest rate.
} 


$$
V_{\mathrm{t}}=\psi_{1}\left(\pi_{\mathrm{t}, 12}^{\mathrm{e}}-\pi_{\mathrm{t}+12}\right)-r r_{\mathrm{t}}-\psi_{0}
$$

where $\psi_{0}$ and $\psi_{1}$ have the same interpretation as $\phi_{0}$ and $\phi_{1}$, respectively, and $\pi_{\mathrm{t}, 12}{ }^{\mathrm{e}}$ are the surveyed (observed) financial analysts' inflation expectations. Now the idea of the test is straightforward.

The null hypothesis is formally defined as

$$
\mathrm{H}_{0}: \quad \pi_{\mathrm{t}, 12}^{\mathrm{e}}=\Pi_{\mathrm{t}, 12} \mathrm{e}^{\mathrm{e}},
$$

where again $\pi_{\mathrm{t}, 12}{ }^{\mathrm{e}}$ denotes the surveyed inflation expectations formed at the beginning of period $t$ for the time horizon till $t+12$, and $\Pi_{t, 12}$ ere the true market expectations for the same period of time. In the light of $\mathrm{H}_{0}$ we can see that if it holds, then expressions (5) and (6) must coincide $\left(\psi_{0}=\phi_{0}\right.$ and $\left.\psi_{1}=\phi_{1}\right)$.

Now substituting $v v_{t}$ instead of $v_{t}$ in (4) and rearranging, one obtains

$$
\mathrm{i}_{\mathrm{t}}=\left(\phi_{0}-\psi_{0}\right)+\left(\phi_{1}-\psi_{1}\right) \pi_{\mathrm{t}+12}+\psi_{1} \pi_{\mathrm{t}, 12}^{\mathrm{e}}+\mathrm{r}_{\mathrm{t}}
$$

After further simplification, a final testing expression is generated:

$$
\mathrm{i}_{\mathrm{t}}=\mathrm{a}_{\mathrm{r}}+\mathrm{a} \pi_{\mathrm{t}+12}+\mathrm{b} \pi_{\mathrm{t}, 12}^{\mathrm{e}}+\varepsilon_{\mathrm{t}}
$$

If the following requirements hold, then one may conclude that $\pi_{t, 12}{ }^{e}=\Pi_{t, 12}{ }^{e}$, or at least they are very close to each other: (i) if $\psi_{0}=\phi_{0}$ and $\psi_{1}=\phi_{1}$, then it must be that $a_{r}=a=0$ and (ii) $b$ must be statistically significant and positive. 
When performing the test, one ought to be aware of the three major weaknesses the test suffers from. The first concerns the character of disturbances in (8).

By definition they can (i), in the best case, follow a stationary process or (ii), in the worst case, they can contain a unit root. In the former case, the test is still usable. One just has to correct for the autocorrelation effect on the parameters' standard error estimates. The parameters' unbiasedness and consistency property remain unaffected.

In the worst case, when residuals contain a unit root, the test fails because of a spurious regression. This occurrence is not unlikely because if we are aware of the real interest rate being a function of marginal productivity, then for an economy in transition the real interest rate can easily be a non-stationary process. ${ }^{4}$ Given this possibility, an essential part of the methodology is to test the disturbances for stationarity. The augmented Dickey-Fuller (ADF) test and the Kwiatkowski-Phillips-Schmidt-Shin (KPSS) test are employed.

The second major weakness of the test is the problem of multicollinearity. The occurrence of multicollinearity is very likely, which follows from the nature of the formation of expectations. The closer the expectations are to the $\mathrm{REH}$, the more severe the problem is, since both $\pi_{\mathrm{t}+12}$ and $\pi_{\mathrm{t}, 12} \mathrm{e}$ are regressors.

\footnotetext{
${ }^{4}$ The source of the unit root cannot be $\varepsilon_{t}$. Even if the expectations do not meet the REH, in a stable economic environment, they do not have a diverging mean.
} 
The third considerable weakness the methodology may suffer from is the problem of joint hypothesis. The problem is that the methodology crucially relies on the assumption that the Fisher rule holds. Thus if it happens the null hypothesis is rejected, one cannot be certain whether it is because the market expectations are truly different from the surveyed ones or because the Fisher rule is invalid. Indeed, this is common to all tests of this type. ${ }^{5}$ However, the problem is lessened here. As mentioned in the introductory section, the focus on the problem of inflation expectations is from a macroeconomic perspective, and there the Fisher rule is a standard way to capture the interest rate behavior. In addition, the results in the next section strongly suggest that the Fisher rule holds.

In summary, to test $\mathrm{H}_{0}$, we run the OLS regression of (8) and test whether the parameters $a_{r}, a$, and $b$ are statistically significant. If the parameters $a_{r}$ and $a$ are insignificant and the parameter $\mathrm{b}$ is significant then $\mathrm{H}_{0}$ cannot be rejected. If $\mathrm{H}_{0}$ cannot be rejected, the surveyed inflation expectations are likely to coincide with the market expectations. Accounting for the test weaknesses, an essential part of the test has to be (i) the test of residuals stationarity and the consequent adjustment of critical values, and (ii) a check of the multicollinearity magnitude.

\footnotetext{
${ }^{5}$ Cf. Cambell, Lo and MacKinlay (1997), section 1.5.2.
} 


\section{The Data}

The test developed above is performed on the monthly data of the Czech interbank money market. The source of the data is the Czech National Bank (CNB) and the Czech Statistical Office. For the testing purposes three series of monthly data are employed: (i) the monthly average of nominal one-year interbank interest rate (PRague InterBank Offer Rate, PRIBOR 1Y), (ii) year-toyear CPI inflation, and (iii) year-to-year expected change in the CPI. The expectations have been collected at the beginning of each month. The details of the survey can be found at $h$ ttp://www.cnb.cz. The data range is from 1999:05 to 2003:12. The whole data set is freely accessible at http://home.cergeei.cz/fukac/papers.

Before moving further, let us discuss the data timing. A period $t$ denotes a month. PRIBOR $1 \mathrm{Y}$ is an average of daily rates within the period t. CPI is a measure of the price level within a given period t. The data to construct the CPI are typically collected in the second week of each month. We can roughly think of it as of a monthly price level average. Thus when computing the actual inflation rate one must be careful about the data timing. For our purposes, the year-to-year inflation rate at time $t+12$ is the relative change in CPI between period $t-1$ and $t+11$. Because the information set available to the agents at time t contains only the CPI of $\mathrm{t}-1$ as the latest information about the actual price level, i.e., $\Omega_{\mathrm{t}}=\left\{\mathrm{CPI}_{\mathrm{t}-1,}, \mathrm{CPI}_{\mathrm{t}-2, \ldots\}}\right\}$, then when comparing $\pi_{\mathrm{t}, 12}{ }^{\mathrm{e}}$ with actual inflation over this period, $\pi_{t+12}$ as denoted in equation (8), the actual inflation rate should be computed as $\pi_{\mathrm{t}+12}=1-\left(\mathrm{CPI}_{\mathrm{t}+11} / \mathrm{CPI}_{\mathrm{t}-1}\right)$. 


\section{The Results}

First let us draw attention to the critical values of t-tests employed here, which are described in Appendix A. In the results below, a very low value of DurbinWatson statistics is found which indicates either the presence of a unit root in the residuals or their strong positive autocorrelation. To test for the former, the augmented Dickey-Fuller and Kwiatkowski-Phillips-Schmidt-Shin tests are performed. Since the results summarized in Appendix B do not suggest statistically significant evidence for the presence of the unit root, it is concluded that there is a strong positive autocorrelation.

Because the regression residuals are positively autocorrelated, the parameters' standard errors are biased downwards, and as a consequence, the pivotal statistics of t-tests are biased upwards. By simulating new critical values, the effect of autocorrelation on the test results is eliminated.

Another reason for simulating the t-test critical values, instead of using the Student's distribution, is also the presence of multicollinearity. Appendix C investigates this issue closely. Because the variance inflation factor (VIF), the measure of the magnitude of collinearity, is 1.52 , and a critical value is 10 , it is concluded that multicollinearity is not a significant problem. Despite this however, the parameters' standard errors are affected and simulating critical values accounts for it. 
Finally, the results from the estimation of equation (8) are reported in Table 1 and graphically presented in Figure 3. As follows from the table, the null hypothesis that the market expectations are equal to the surveyed expectations cannot be rejected at the standard level of significance. The parameters $a_{r}$ and a are not significantly different from zero, while the parameter $b$ is found to be significantly different from zero. The goodness of fit is $82 \%$ (without accounting for autocorrelation in residuals). Given these results the joint hypothesis problem is not binding. Parameter $b$ is significant and so the model is also significant.
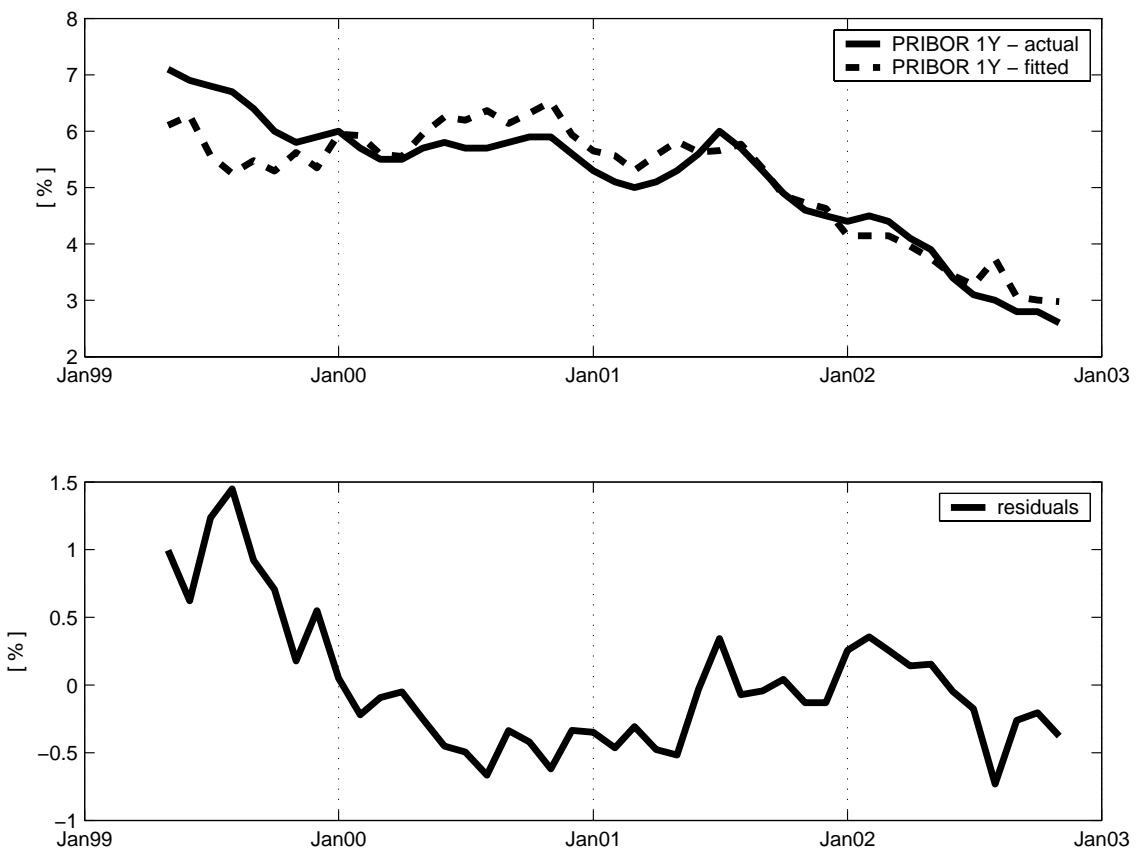

Figure 3 The regression results of equation (8) 
Table $1 \quad i_{t}=a_{r}+a \pi_{t+12}+b \pi_{t, 12}^{e}+\varepsilon_{t}$

\begin{tabular}{ccccccc}
\hline Parameter & Estimate & t-stat. & $\begin{array}{c}\text { Critical } \\
\text { value 5\% }\end{array}$ & DW & $\overline{\mathrm{R}}^{2}$ & $\begin{array}{c}\text { No.of } \\
\text { obs. }\end{array}$ \\
\hline $\mathrm{a}_{\mathrm{r}}$ & 0.2094 & 0.4008 & 4.5052 & & & \\
$\mathrm{a}$ & 01445 & 2.8471 & 4.3978 & 0.32 & 0.79 & 43 \\
$\mathrm{~b}$ & 1.1406 & 7.7296 & 4.6014 & & & \\
\hline
\end{tabular}

Knowing that the estimation results do not suffer from bias or inefficiency, i.e., the model is significant, the residuals' autocorrelation is accounted for, and that there is no multicollinearity problem, the results are somewhat surprising. Given the nature of the interbank money-market, i.e., it is big and highly liquid, one would expect the market expectations to be much more precise than the surveyed ones. In terms of the test, the parameter a should be of a larger value than 0.15. Instead, it is found that, even though the surveyed inflation expectations do not have predictive power for actual inflation, they do not statistically differ from the market expectations. This further suggests that the $\mathrm{REH}$, as understood by macroeconomic theory, is not the best approximation of inflation expectations for the Czech economy.

The surveyed expectations are formed by financial analysts and, in theory, the market expectations should be formed by market dealers who form the market price, $\mathrm{i}_{\mathrm{t}}$. In practice, it is more than likely that the dealers do not pay any attention to the analysts' inflation expectations, or rather the dealers do not have any inflation expectations at all. Their particular objective, as professionals, is to maximize their profit and as a result of their actions to meet 
this criterion, the market price rises. It is surprising that the price PRIBOR $1 \mathrm{Y}$ is inefficient from the macroeconomic point of view, i.e., it is based on inefficient inflation expectations. If we admit the idea that the market-makers do not pay attention to inflation forecasts of their own financial analysists, how are the inefficient inflation forecasts that we see in Figure 1 transmitted into the market price?

The character of the Czech interbank money market and the credit market can offer one possible explanation. The credit market is the main channel used to transmit the capital to the economy. Banks (lenders) are the market price setters, and borrowers are price-takers. The price on the credit market is derived from the price on the interbank money market which, in contrast to the credit market, may be considered a competitive one.

For banks as the major lenders of capital, it is profitable to overshoot their inflation forecasts (expectations). If we believe that bankers take into account a nominal depreciation of money when forming the credit price, overshooting these expectations increases their ex post real revenues. Given that the borrowers are price-takers, the overshooting is accepted. Let us assume that a bank on the Czech credit market sets the one-year nominal interest rate on credit so that it is composed of an individual PRIBOR $1 \mathrm{Y}$ estimate plus a risk premium and a profit margin. The individual bank's PRIBOR $1 \mathrm{Y}$ estimate is composed of a required minimum ex ante real return plus an expected nominal depreciation (expected inflation). Having a price on the credit market, the 
lenders face a possible lack or excess of loanable funds (deposits from clients). To utilize them, they are motivated to enter the interbank money market and trade them. Under the assumption that the pricing rule is the same for all banks in the credit market, there will be only a moderate correction in the market PRIBOR in order to make the market clear. The new market PRIBOR is recursively reflected in the price on the credit market.

In this story, the money-market dealers do not necessarily need to know the inflation expectations the market price includes or even how the credit price is formed. They are only "endowed" with an excess or deficit of money which they trade. The deficits or excesses of loanable funds are determined by the credit market, which is exogenous to the interbank money market.

\section{Conclusion}

In this paper we find that inefficient surveyed inflation expectations have predictive power on the interest rate and that they do not differ from the market expectations in a significant way. This has crucial consequences for modeling the Czech economy and particularly for optimal monetary policy. As Orphanides and Williams (2002) and Evans and Honkapohja (2002) find, optimal monetary policy differs for an economy where the REH is valid, and for an economy where the expectations do not meet the REH requirements. What is found optimal in the REH world is not optimal in the bounded rationality world, and vice versa. Macroeconomists and policy-makers ought to be aware of this fact. 
Nonetheless, the research has produced more questions than answers. The findings call for a study on why the Czech Interbank money market anticipates inefficient expectations, and why there is no arbitrage incentive to improve this. Given that the market has a unique position in the financial system, in general, it is not possible that the results found here would hold in the long run. Hence, although we make some headway towards explaining how the inefficient inflation forecasts are transmitted into the market price, a serious attempt to find the final answer should still be made. Having a better understanding of how the market functions, we are in a better position to improve our economic models and to suggest optimal policies. 


\section{References}

Cambell, Z., A. W. Lo and C. MacKinlay (1997), The Economics of Financial Markets, Princeton University Press.

Enders, W. (1995), Applied Econometrics Time Series, John Wiley and Sons., Inc., New York.

Evans, G. W. and S. Honkapohja (2002), 'Adaptive Learning and Monetary Policy Design', In: Journal of Money, Credit and Banking Conference.

Fama, E.F. and M.R. Gibbons (1982), 'Inflation, Real Returns and Capital Investment', Journal of Monetary Economics (9), 297-323.

Granger, C.W.J. and P. Newbold (1974), 'Spurious Regressions in Econometrics', Journal of Econometrics (2), 111-120.

Kwiatkowski, D., P. Phillips, P.Schmidt and Y. Shin (1992), 'Testing the Null Hypothesis of Stationarity against the Alternative of a Unit Root: How Sure Are We that Economic Time Series are Non-Stationary?', Journal of Econometrics (54), 159-178.

Mankiw, N.G. and J. Wolfers (2003), 'Disagreement about Inflation Expectations', NBER Macroeconomics Annual (18).

Mishkin F. (1990a), 'What Does the Term Structure Tell Us About Future Inflation?', Journal of Monetary Economics 25(1), 77-76.

Orphanides A. and J.C. Williams (2002), 'Imperfect Knowledge, Inflation Expectations, and Monetary Policy', Working Paper of the Federal Reserve Bank of San Francisco.

Phillips P.C.B. (1986), 'Understanding Spurious Regressions in Econometrics', Journal of Econometrics 33(3), 311-40.

Pindyck R.S. and D.L. Rubinsfeld (1998), Econometric Models and Economic Forecasts, Third Edition. McGraw-Hill.

Podpiera R. (2003), 'Macroeconomic News and Market Efficiency', The Economics of Transition. 


\section{Appendix A}

In this appendix, the methodology for obtaining the critical values reported in the text is outlined. The methodology relies on Monte Carlo experiments. Mishkin (1990b) was the motivation for this approach.

The methodology can be summarized in the few following steps:

1. Analyze the time series of model variables, i.e., PRIBOR 1Y, year-to-year inflation, and inflation expectations, on the unit root.

2. Apply the Box-Jenkins methodology on the data. The outcome ought to be an $\operatorname{ARIMA}(p, d, q)$ model with the best fit possible.

3. Simulate the estimated models from the previous step.

4. Using the simulated time series, estimate equation (8), and save the results on the t-tests.

5. Repeat steps 3.) and 4.) 10,000 times.

6. From step 5.) construct a new distribution for critical values.

The simulated critical values are reported in Table 2.

Table 2 The simulated critical values

\begin{tabular}{ccccc}
\hline Parameter & $\mathbf{2 5 \%}$ & $\mathbf{1 0 \%}$ & $\mathbf{5 \%}$ & $\mathbf{1 \%}$ \\
\hline $\mathrm{a}_{\mathrm{r}}$ & 1.7339 & 3.6738 & 4.5052 & 7.2765 \\
$\mathrm{a}$ & 1.7232 & 3.4252 & 4.3978 & 6.8293 \\
$\mathrm{~b}$ & 1.8041 & 3.4825 & 4.6014 & 6.8393 \\
\hline
\end{tabular}




\section{Appendix B}

The regression residuals from (8) are tested for a unit root here. Testing for a unit root is crucial for the regression results, because residuals are partially estimates of real interest rate, and there might be an economic reason to believe that a unit root

is present. If it is so, then the results are spurious and non-usable. ${ }^{6}$ To test for the unit root, the augmented Dickey-Fuller (ADF) and Kwiatkowski-PhillipsSchmidt-Shin (KPSS) tests are employed. Each of them test for a unit root but from a different view. The null hypothesis of the ADF test is that a time series is not stationary while the null hypothesis of the KPSS test is that a time series is stationary. Applying both tests provides a more complex picture than using only one of them.

The results for the ADF test are summarized in Table 3 Following Enders (1995), the ADF test is based on testing $\mathrm{H}_{0}: \gamma=0$ in

$$
\Delta \hat{\varepsilon}_{t}=\gamma \hat{\varepsilon}_{t-1}+\sum_{i=2}^{p} \beta_{i} \Delta \hat{\varepsilon}_{t-i+1}+v_{t}
$$

Table $3 \quad$ Augmented Dickey-Fuller Test Results

\begin{tabular}{cccccc}
\hline Parameter & Estimate & t-test & t-crit. & $\begin{array}{c}\text { F-test } \\
\text { (p-value) }\end{array}$ & $\begin{array}{c}\text { Q-test } \\
\text { (crit.val.) }\end{array}$ \\
\hline$\gamma$ & -0.2192 & -7.5765 & -1.95 & & \\
$\beta_{1}$ & -0.0115 & -0.1414 & -1.69 & 5.65 & 17.28 \\
$\beta_{2}$ & -0.1728 & -2.3414 & -1.69 & $(0.02)$ & $(25.70)$ \\
\hline
\end{tabular}

\footnotetext{
${ }^{6}$ For details on spurious regression, refer to Granger and Newbold (1978) who experimentally demonstrated the consequences of unit root on regression results, and to Phillips (1986) who formalized their results.
} 
The critical values in Table 3are for the $5 \%$ level of significance. The null hypotheses of residuals being non-stationary is rejected $(\gamma \neq 0)$.

The KPSS test results are summarized in Table 4. The test statistics are computed for the lag truncation parameter, $I$, from 0 to 8 . As argued by Kwiatkowski et al. (1992), for $I=8$ the test has the largest power. Including $l=0$, the test also accounts for autocorrelation. The critical value for the test at the $5 \%$ significance level is 0.463 .

Table $4 \quad$ KPSS Test Results

\begin{tabular}{cccccccccc}
\hline $\mathbf{I}$ & $\mathbf{0}$ & $\mathbf{1}$ & $\mathbf{2}$ & $\mathbf{3}$ & $\mathbf{4}$ & $\mathbf{5}$ & $\mathbf{6}$ & $\mathbf{7}$ & $\mathbf{8}$ \\
\hline$\hat{\varepsilon}_{t}$ & $\mathbf{1 . 1 0}$ & $\mathbf{0 . 6 2}$ & $\mathbf{0 . 4 7}$ & 0.38 & 0.32 & 0.29 & 0.26 & 0.25 & 0.24 \\
\hline
\end{tabular}

The results from the KPSS test suggest that the regression residuals from estimating (8) are stationary. For $l=2$ the test result is on the margin of statistical significance. Putting the result together with the ADF test, it may be concluded that the residuals

do not contain a unit root and follow a stationary process. Consequently, the parameter estimates reported above are unbiased and consistent, although inefficient. 


\section{Appendix C}

In this section the collinearity issue is addressed. First, a formal test for the presence of collinearity is performed. At the same time the test is also a test of the rational expectations hypothesis. Second, the effect of collinearity on parameters' estimates and their standard errors is quantitatively analyzed.

\section{The test of collinearity}

The test is standard to the econometric literature. It is based on a variance inflation factor estimation. Because it tests for the linear relationship between $\pi_{t+12}$ and $\pi_{t, 12}{ }^{e}$, the test is at the same time a test of the REH.

The REH is usually tested on the following inflation-prediction equation:

$$
\pi_{\mathrm{t}+12}=\mathrm{c}_{1}+\mathrm{c}_{2} \pi_{\mathrm{t}, 12}^{\mathrm{e}}+\mathrm{v}_{\mathrm{t}+12}
$$

If the REH holds, parameter $c_{1}$ is zero, $c_{2}$ is equal to 1 , and $v_{t+12}$ is an i.i.d. process with zero mean and finite variance. In this case the two variables are evidently collinear.

When the inflation-prediction equation is estimated, $\overline{\mathrm{R}}^{2}$ is used to evaluate collinearity. To this purpose a variance inflation factor (VIF) is computed:

$$
\mathrm{VIF}=\frac{1}{1-\overline{\mathrm{R}}^{2}}
$$

Usually, we face a problem of collinearity if VIF>10. 
The estimation results of the inflation-prediction equation are summarized in Table 5.

\begin{tabular}{|c|c|c|c|c|c|c|}
\hline & & bble 5 & $\pi_{\mathrm{t}+12}=\mathrm{c}_{1}+$ & ${ }_{12}^{e}+v_{t+}$ & & \\
\hline Parameter & Estimate & t-stat. & $\begin{array}{c}\text { Critical } \\
\text { value } 5 \%\end{array}$ & DW & $\overline{\mathrm{R}}^{2}$ & $\begin{array}{l}\text { No.of } \\
\text { obs. }\end{array}$ \\
\hline $\mathrm{C}_{1}$ & -4.3353 & -2.9835 & & \multirow{2}{*}{0.16} & \multirow{2}{*}{0.34} & \multirow{2}{*}{44} \\
\hline $\mathrm{c}_{2}$ & 1.7051 & 4.8067 & & & & \\
\hline
\end{tabular}

Note: The critical values are simulated similarly as in Appendix $\bar{A}$.

First, we can see that $\mathrm{c}_{1} \neq 0, \mathrm{c}_{2} \neq 1$, and the residuals are positively autocorrelated. As a consequence, the REH cannot be accepted. Second, the VIF is 1.5 which is far from the value where collinearity causes estimation problems.

\section{The Quantitative Assessment of the Collinearity Effect on Estimation}

Let us derive the estimates $\left\{\hat{a}_{r}, \hat{a}, \hat{b}\right\}$ of equation (8):

$$
\mathrm{i}_{\mathrm{t}}=\mathrm{a}_{\mathrm{r}}+\mathrm{a} \pi_{\mathrm{t}+12}+\mathrm{b} \pi_{\mathrm{t}, 12}{ }^{\mathrm{e}}+\varepsilon_{\mathrm{t}} .
$$

To find the estimates of the parameters, the ordinary least-square criteria is used:

$$
\sum_{t=1}^{N}\left(\mathrm{i}_{\mathrm{t}}-\mathrm{a}_{\mathrm{r}}-\mathrm{a} \pi_{\mathrm{t}+12}-\mathrm{b} \pi_{\mathrm{t}, 12}^{\mathrm{e}}\right)^{2} \rightarrow \min .
$$

Minimizing the criterion gives rise to the set of normal equations 


$$
\begin{aligned}
& 0=\sum 2\left(i_{t}-a_{r}-a \pi_{t+12}-b \pi_{t, 12}^{e}\right)(-1), \\
& 0=\sum 2\left(i_{t}-a_{r}-a \pi_{t+12}-b \pi_{t, 12}^{e}\right)\left(-\pi_{t+12}\right), \\
& 0=\sum 2\left(i_{t}-a_{r}-a \pi_{t+12}-b \pi_{t, 12}^{e}\right)\left(-\pi_{t, 12}^{e}\right),
\end{aligned}
$$

which can be conveniently rewritten as

$$
\begin{aligned}
& 0=\overline{\mathrm{i}}-\hat{\mathrm{a}} \bar{\pi}-\hat{\mathrm{b}} \bar{\pi}^{\mathrm{e}}, \\
& 0=\operatorname{cov}\left(\mathrm{i}_{\mathrm{t}}, \pi_{\mathrm{t}+12}\right)-\hat{\mathrm{a}} \operatorname{var}\left(\pi_{\mathrm{t}+12}\right)-\hat{\mathrm{b}} \operatorname{cov}\left(\pi_{\mathrm{t}+12}, \pi_{\mathrm{t}, 12}^{\mathrm{e}}\right), \\
& 0=\operatorname{cov}\left(\mathrm{i}_{\mathrm{t}}, \pi_{\mathrm{t}, 12}^{\mathrm{e}}\right)-\hat{\mathrm{a}} \operatorname{cov}\left(\pi_{\mathrm{t}+12}, \pi_{\mathrm{t}+12}^{\mathrm{e}}\right)-\hat{\mathrm{b}} \operatorname{var}\left(\pi_{\mathrm{t}, 12}^{\mathrm{e}}\right),
\end{aligned}
$$

where $\bar{x}=\frac{1}{N} \sum_{t=1}^{N} x_{t}$. Or in a matrix form

$$
\left[\begin{array}{c}
\hat{a} \\
\hat{b}
\end{array}\right]\left[\begin{array}{cc}
\operatorname{var}\left(\pi_{t+12}\right) & \operatorname{cov}\left(\pi_{t+12}, \pi_{t, 12}^{\mathrm{e}}\right) \\
\operatorname{cov}\left(\pi_{\mathrm{t}, 12}^{\mathrm{e}}, \pi_{\mathrm{t}+12}\right) & \operatorname{var}\left(\pi_{\mathrm{t}, 12}^{\mathrm{e}}\right)
\end{array}\right]=\left[\begin{array}{c}
\operatorname{cov}\left(\mathrm{i}_{\mathrm{t}}, \pi_{\mathrm{t}+12}\right) \\
\operatorname{cov}\left(\mathrm{i}_{\mathrm{t}}, \pi_{\mathrm{t}, 12}^{\mathrm{e}}\right)
\end{array}\right],
$$

where $\left[\begin{array}{cc}\operatorname{var}\left(\pi_{\mathrm{t}+12}\right) & \operatorname{cov}\left(\pi_{\mathrm{t}+12}, \pi_{\mathrm{t}, 12}^{\mathrm{e}}\right) \\ \operatorname{cov}\left(\pi_{\mathrm{t}, 12}^{\mathrm{e}}, \pi_{\mathrm{t}+12}\right) & \operatorname{var}\left(\pi_{\mathrm{t}, 12}^{\mathrm{e}}\right)\end{array}\right]$ is the information matrix $\mathbf{X}^{\prime} \mathbf{X}$.

Solving for the parameter estimates gives

$$
\begin{aligned}
& \hat{b}=\frac{1}{1-\rho^{2}} \frac{\operatorname{cov}\left(i_{t}, \pi_{t, 12}^{e}\right)}{\operatorname{var}\left(\pi_{t, 12}^{e}\right)}-\frac{\rho}{1-\rho} \frac{\operatorname{cov}\left(i_{t}, \pi_{t+12}\right)}{\operatorname{std}\left(\pi_{t+12}\right) \operatorname{std}\left(\pi_{t, 12}^{e}\right)}, \\
& \hat{a}=\frac{\operatorname{cov}\left(i_{t}, \pi_{t+12}\right)}{\operatorname{var}\left(\pi_{t+12}\right)}-\hat{b} \rho \frac{\operatorname{std}\left(\pi_{t, 12}^{e}\right)}{\pi_{t+12}}, \\
& \hat{a}_{r}=\bar{i}-\hat{a} \bar{\pi}-\hat{b} \bar{\pi}^{e}
\end{aligned}
$$

where $\rho=\frac{\operatorname{cov}\left(\pi_{\mathrm{t}+12}, \pi_{\mathrm{t}, 12}^{\mathrm{e}}\right)}{\operatorname{std}\left(\pi_{\mathrm{t}+12}\right) \operatorname{std}\left(\pi_{\mathrm{t}, 12}^{\mathrm{e}}\right)} \cdot 7$

Next, to evaluate the impact of collinearity on the t-test, we have to analyze its effect on parameters' standard errors. For simplicity, let us assume that

\footnotetext{
${ }^{7}$ Note that $r=0$ gives rise to a standard OLS estimate.
} 
regression residuals are homoscedastic and uncorrelated. Then the parameters' variance can be expressed as

$$
\begin{aligned}
\operatorname{var}\left[\begin{array}{c}
\hat{a} \\
\hat{b}
\end{array}\right] & =\sigma^{2}\left(\mathbf{X}^{\prime} \mathbf{X}\right)^{-1}=\sigma^{2}\left[\begin{array}{cc}
\operatorname{var}\left(\pi_{\mathrm{t}+12}\right) & \operatorname{cov}\left(\pi_{\mathrm{t}+12}, \pi_{\mathrm{t}, 12}^{\mathrm{e}}\right) \\
\operatorname{cov}\left(\pi_{\mathrm{t}, 12}^{\mathrm{e}}, \pi_{\mathrm{t}+12}\right) & \operatorname{var}\left(\pi_{\mathrm{t}, 12}^{\mathrm{e}}\right)
\end{array}\right]^{-1}= \\
& =\sigma^{2}\left[\begin{array}{cc}
\operatorname{var}\left(\pi_{\mathrm{t}+12}\right) & \rho \operatorname{std}\left(\pi_{\mathrm{t}+12}\right) \operatorname{std}\left(\pi_{\mathrm{t}, 12}^{\mathrm{e}}\right) \\
\rho \operatorname{std}\left(\pi_{\mathrm{t}, 12}^{\mathrm{e}}\right) \operatorname{std}\left(\pi_{\mathrm{t}+12}\right) & \operatorname{var}\left(\pi_{\mathrm{t}, 12}^{\mathrm{e}}\right)
\end{array}\right]^{-1}= \\
& =\frac{\sigma^{2}}{\left(1-\rho^{2}\right) \operatorname{var}\left(\pi_{\mathrm{t}+12}\right) \operatorname{var}\left(\pi_{\mathrm{t}, 12}^{\mathrm{e}}\right)}\left[\begin{array}{cc}
\operatorname{var}\left(\pi_{\mathrm{t}+12}\right) & \rho \operatorname{std}\left(\pi_{\mathrm{t}+12}\right) \operatorname{std}\left(\pi_{\mathrm{t}, 12}^{\mathrm{e}}\right) \\
\rho \operatorname{std}\left(\pi_{\mathrm{t}, 12}^{\mathrm{e}}\right) \operatorname{std}\left(\pi_{\mathrm{t}+12}\right) & \operatorname{var}\left(\pi_{\mathrm{t}, 12}^{\mathrm{e}}\right)
\end{array}\right], \\
\operatorname{var}\left(\hat{\mathrm{a}}_{\mathrm{r}}\right) & =\bar{\pi}^{2} \operatorname{var}(\hat{\mathrm{a}})+\bar{\pi}^{\mathrm{e} 2} \operatorname{var}(\hat{\mathrm{b}}) .
\end{aligned}
$$

The analysis is limited for the above case only. Because the autocorrelation is accounted for in the critical values, this limitation is suitable for further purposes.

To quantitatively analyze the influence of collinearity on the parameters' estimates and t-tests, their values are simulated for different magnitudes of correlation $(\rho)$ between $\pi_{t+12}$ and $\pi_{t, 12}{ }^{e}$. The analysis is conducted on the set of descriptive statistics summarized in Table 6 . 


\begin{tabular}{cc}
\hline Statistics & Estimate \\
\hline$\rho$ & 0.5957 \\
$\operatorname{cov}\left(i_{\mathrm{t}}, \pi_{\mathrm{t}+12}\right)$ & 1.6795 \\
$\operatorname{cov}\left(\mathrm{i}_{\mathrm{t}}, \pi_{\mathrm{t}, 12}{ }^{\mathrm{e}}\right)$ & 0.7405 \\
$\operatorname{std}\left(\pi_{\mathrm{t}+12}\right)$ & 2.0575 \\
$\operatorname{std}\left(\pi_{\mathrm{t}, 12}{ }^{\mathrm{e}}\right)$ & 0.7188 \\
$\operatorname{var}\left(\pi_{\mathrm{t}+12}\right)$ & 4.2332 \\
$\operatorname{var}\left(\pi_{\mathrm{t}, 12}{ }^{\mathrm{e}}\right)$ & 0.5167 \\
$\overline{\mathrm{i}}$ & 5.2000 \\
$\bar{\pi}$ & 2.5432 \\
$\bar{\pi}^{\mathrm{e}}$ & 4.0341 \\
\hline
\end{tabular}

From the graphical results (Figures $4-6$ ) follows that only the parameter a is sensitive to the value of $\rho$. Its estimate differs considerably for $\rho=0$ and $\rho=.6$ and so do the t-statistics. However, what is important here is that the parameter is not statistically significant for $\rho=(.5, .9)$. By the nature of expectations, the correlation between $\pi_{\mathrm{t}, 12}{ }^{\mathrm{e}}$ and $\pi_{\mathrm{t}+12}$ should not be very low, even though the REH does not hold.

The parameter $a_{r}$ is always statistically insignificant and $b$ is statistically significant under the simulation setup. Hence, it might be concluded the results presented in the paper are robust for $\rho=(0.5,0.9)$. 

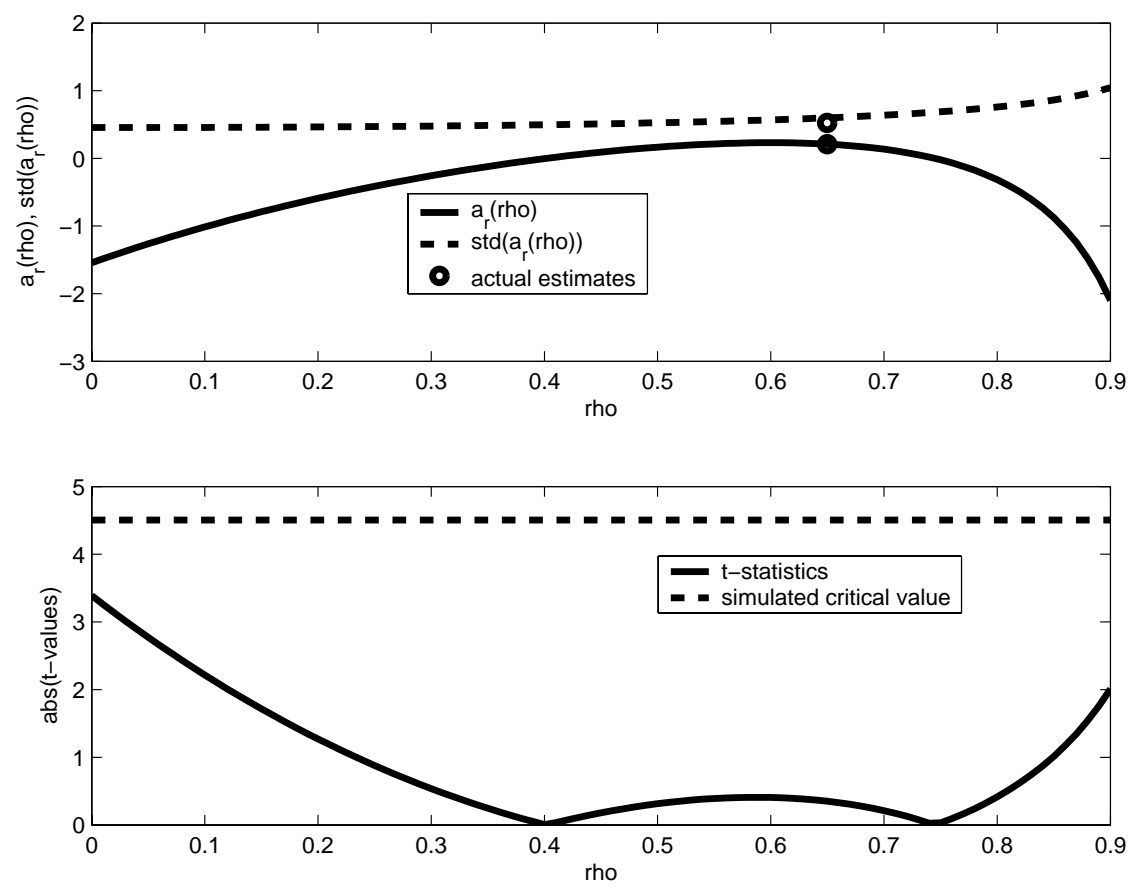

Figure 4 Dependence of $\hat{\mathbf{a}}_{\mathrm{r}}$ and its t-statistics on $\rho$.
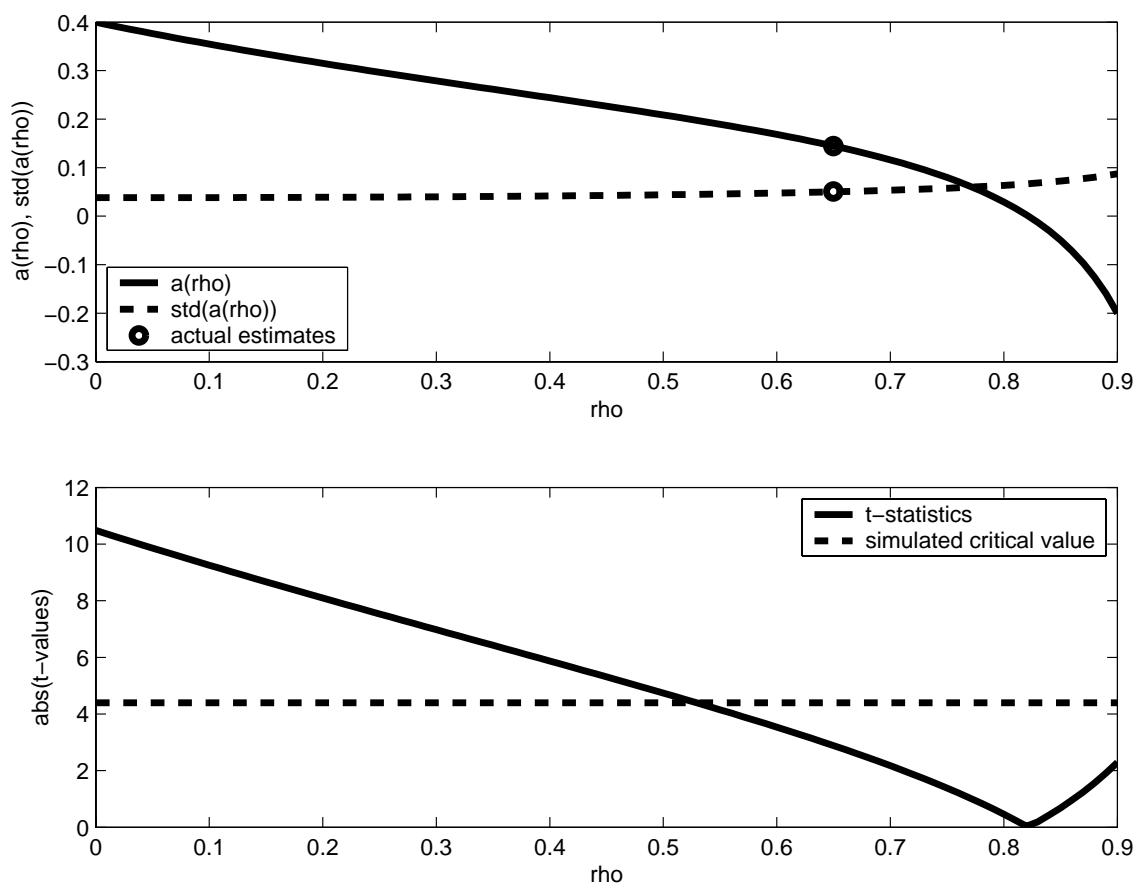

Figure 5 Dependence of $\hat{a}$ and its t-statistics on $\rho$. 

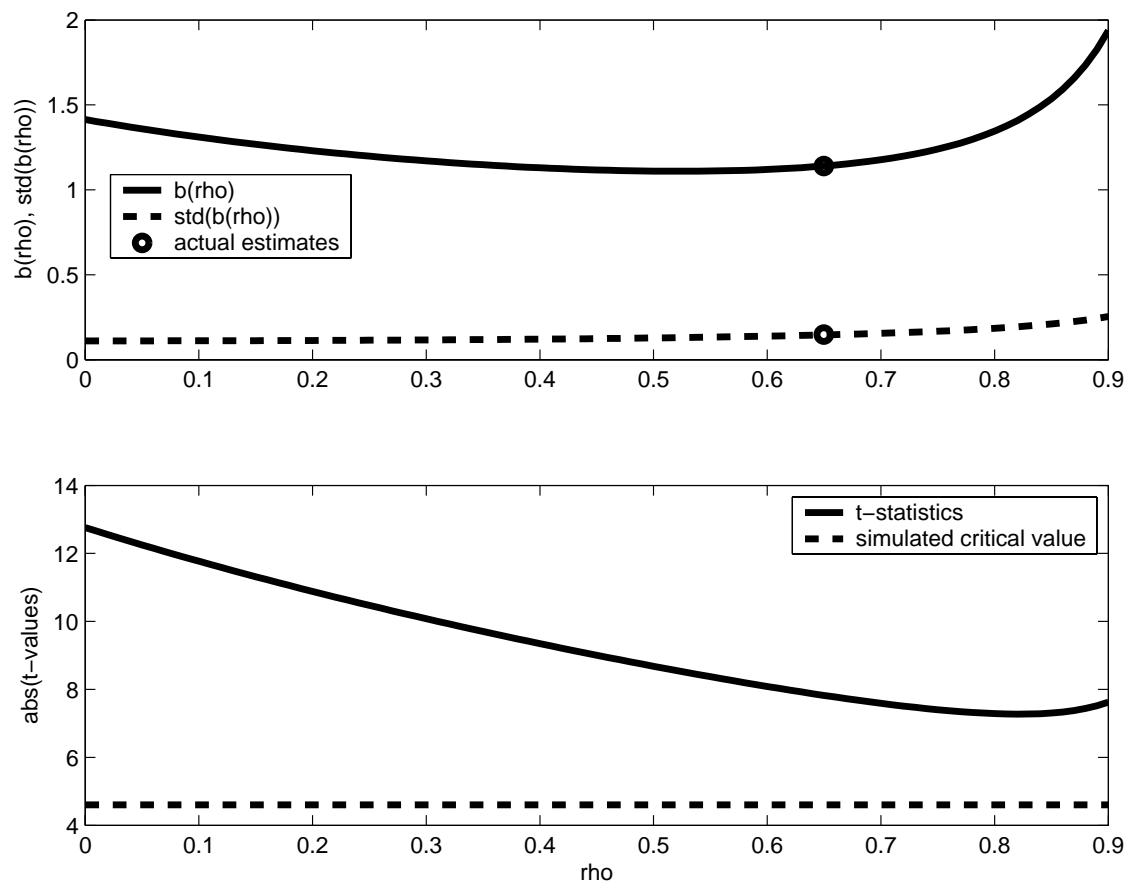

Figure 6 Dependence of $\hat{b}$ and its t-statistics on $\rho$. 
Individual researchers, as well as the on-line and printed version of the CERGE-EI Working Papers Series (including their dissemination) were supported from the following institutional grants:

- Economic Aspects of EU and EMU Entry [Ekonomické aspekty vstupu do Evropské unie a Evropské měnové unie], No. AVOZ70850503, (2005-2010);

- Economic Impact of European Integration on the Czech Republic [Ekonomické dopady evropské integrace na ČR], No. MSM0021620846, (2005-2011);

Specific research support and/or other grants the researchers/publications benefited from are acknowledged at the beginning of the Paper.

(c) Martin Fukač, 2005

All rights reserved. No part of this publication may be reproduced, stored in a retrieval system or transmitted in any form or by any means, electronic, mechanical or photocopying, recording, or otherwise without the prior permission of the publisher.

Published by

Charles University in Prague, Center for Economic Research and Graduate Education (CERGE) and

Economics Institute (EI), Academy of Sciences of the Czech Republic

CERGE-El, Politických vězñu 7, 11121 Prague 1, tel.: +420 224005 153, Czech Republic.

Printed by CERGE-EI, Prague

Subscription: CERGE-El homepage: http://www.cerge-ei.cz

Editors: Directors of CERGE and EI

Managing editors: Deputy Directors for Research of CERGE and EI

ISSN 1211-3298

ISBN 80-7343-046-0 (Univerzita Karlova v Praze, CERGE)

ISBN 80-7344-035-0 (Národohospodářský ústav AV ČR, Praha) 
CERGE-EI

P.O.BOX 882

Politických vězňů 7

11121 Praha 1

Czech Republic http://www.cerge-ei.cz 